\title{
Roles of Fear of Happiness and Fragility of Happiness in Nigerian Military Personnel Workload
}

\author{
Ikechukwu V. N. Ujoatuonu ${ }^{1}$, Chiedozie O. Okafor ${ }^{2}$, Gabriel C. Kanu ${ }^{1}$, Izuchukwu L. G. Ndukahie ${ }^{2} \&$ Raphael $^{2}$ \\ Nwaleke ${ }^{1}$ \\ ${ }^{1}$ Department of Psychology, Faculty of the Social Sciences, University of Nigeria, Nsukka \\ ${ }^{2}$ Department of Psychology, Alex Ekwueme Federal University, Ndufu-Alike, Ebonyi State, Nigeria \\ Correspondence: Chiedozie O. Okafor, Department of Psychology, Alex Ekwueme Federal University, \\ Ndufu-Alike, Ebonyi State, Nigeria.
}

Received: November 2, 2020

Accepted: November 26, 2020

Online Published: November 27, 2020

doi:10.5539/ijps.v12n4p53

URL: https://doi.org/10.5539/ijps.v12n4p53

\begin{abstract}
In the light of conflicts and Boko Haram insurgency facing Nigeria as a county and the involvement of the military in the fight against terrorists, the study of workload and happiness need to be researched more to gain greater acceptance and become one of the global indices on which nations' military are measured and ranked. Our study anchors on multiple resource and information processing theory to assess the roles of fear and fragility of happiness in workload among Nigerian military personnel. Two hundred and twenty (220) Nigerian soldiers, drawn from Nigerian Army and Nigerian Air Force participated in this study. Three instruments, namely, Workload Scale, Fear of Happiness Scale and Fragility of Happiness Scale, were used to collect data from the participants. Results of hierarchical multiple regression analysis indicated that fear of happiness was not significantly associated with work load. Fragility of happiness positively predicted work load, indicating that military personnel who had greater fragility of happiness reported greater workload. It was concluded that workplace interventions and programs to curtail fragility of happiness would be helpful in reducing the perceptions of excess workload among Nigerian military personnel.
\end{abstract}

Keywords: combat, fear of happiness, fragility of happiness, military personnel, workload

\section{Introduction}

The military organization embodies one of the most risky and demanding outfitted formation (Billing \& Drain, 2017), especially for countries having security challenges, conflicts, combats and wars (Ujoatuonu, Onyishi, Okafor, Amazue, \& Umeh, 2020). These can be said to be in line with Swarnalatha (2013) statement that the concept of workload has diverse facets to include physical, mental, physiological demand and frustration stages. This is because physical, physiological and mental loads that arise from these conflicts, challenges, combats and wars tend to amplify military personnel workload (Hollands, Spivak, \& Kramkowski, 2019), which in turn compromise their operational performance (Skinner \& Simpson, 2002), combat experiences (Mao, Xie, Hu, \& Su, 2014), job characteristics, thriving at work (DeBusk, Hill, Chander, Knight, \& Babski-Reeves, 2018), organizational commitment and job satisfaction (Diaz-Piedra, Sebastián, \& Di Stasi, 2020) and career adaptation. Military workload in countries facing challenges, conflicts, Fulani banditry and resurgences is unavoidable, no matter the type of cognitive and physical training introduced by the defense organization designed to enhance practical and elevated-order cognitive ability (Ujoatuonu, Onyishi, Okafor, Amazue, \& Umeh, 2020).

Swarnalatha (2013) defined workload as the cost (e.g., fatigue, stress, errors and pressures) of accomplishing a task within a specific time frame by an employee to accomplish organizational goal, personal and family commitment. For that reason, the military organization is devoted to discover answers to lessen personnel workload (Mitchell, 2000) as their job analysis, description and characteristics are embedded in their vocational identity and workload. To understand the concept of workload which is inevitable in military organizational context, the facets of happiness needs to be looked at to comprehend the physiological, physical and psychological mechanisms (Billing \& Drain, 2017). Agbo, Nzeadibe and Ajaero (2012) asserted that happiness in Nigeria is a therapeutic intervention against negative feelings, harsh socio-economic conditions, corruption, ethnocentrism and bigotry her citizens experience every day. Our study was triggered by several complaints 
from Nigerian military personnel which contradicted news from the media on workload, motivation, happiness, vocational identity, combat exposure, career adaptation and organizational commitment.

The challenges and conflicts facing Nigeria introduced new battle management methods (Ujoatuonu, Kanu, \& Apex-Apeh, 2017) which has altered soldier happiness and increased military workload. This is because military acts entail personnel to consistently perform their duties (Baba, Ujoatuonu, Ogba, \& Kanu, 2019) not minding the experiences of happiness and workload. But the big question is "can individuals report high levels of happiness in the absence of things that are supposed to make them happy, and in presence of heavy workload?" The answer is inconclusive as Nigerian military tasks most times require soldiers' participation in politics (Ujoatuonu, Kanu, \& Apex-Apeh, 2017) which can lead to mental fatigue, increased workload, decreased performance and influence happiness. As a soldier, being in the warfront means facing life threatening work situation and workload for one's nation, state and family (Diaz-Piedra, Sebastián, \& Di Stasi, 2020) which can influence experiences of happiness. Fear of being attacked at combat, non-payment of allowances, questions of meaning in life and downplayed causalities of military personnel in combat (Ujoatuonu, Kanu, Ugwuibe, \& Mbah, 2019) are other factors that might alter the experiences of happiness and workload of Nigerian soldiers.

In the realization of positive experiences, happiness is one of the utmost drives of every individual on earth (Joshanloo, 2013a); but because of the obvious nature of military job that involves discipline, sacrifice, fit, commitment (Baba, Ujoatuonu, Ogba, \& Kanu, 2019) vocational identity, high spirit with energy at work (Ujoatuonu, Kanu, \& Apex-Apeh, 2017), happiness is needed for physical, emotional and mental adaptation to survive in combat. When soldiers perceive increased workload, unfavourable physical, emotional and mental harm or death in battle, such as that experienced by soldiers deployed to the north-east, central and western part of Nigeria to combat Boko Haram resurgences, they may report life dissatisfaction and increased negative affect. Some Nigerian military personnel confided in us that the Nigerian defence organization was gravely under-equipped. This has possibly made unhappy soldiers engage in counterproductive actions to attain happiness. Also, as reported in one of our interviews, under-equipment of the Nigerian defence organization seems to have influenced fear and fragility of happiness and set-off other negative emotions like worry, apprehension and suspicions.

Fragility of happiness exists when there is a thin line linking happiness with unhappiness which creates apprehension that with a simple mishap and/or mistake, something can change happiness to unhappiness (that happiness is temporary and may be easily replaced by neutral or unpleasant states) (Joshanloo, Weijers, Jiang, Han, Bae, Pang, Ho, Ferreira, Demir, Rizwan, Khilji, Achoui, Asano, Igarashi, Tsukamoto, Lamers, Turan, Sundaram, Yeung, Poon, Lepshokova, Panyusheva, \& Natalia, 2015). On the same continuum, the nature of optimism and breakable happiness (Joshanloo, Park, \& Park, 2017), personality traits, materialism, wellbeing (Joshanloo, 2019) with workload prediction and assessment (Joshanloo, Park, \& Park, 2017) might possibly be related to subjective wellbeing. Since stronger support of brittle happiness is associated with lower dispositional optimism and personal growth (Joshanloo, 2018) with higher fear of happiness and workload, such a cynical viewpoint can per se deflate subjective wellbeing of soldiers (Reid \& Nygren, 1988).

Our study is anchored on multiple resource theory which suggests that fear of being happy in combat hinders workload because of the finite capacity of humans in their distribution of tasks and information across various sensory modalities (Wickens, 2008). For example, if an individual is asked to perform two simultaneous responsibilities, the performance of one or both of the tasks may suffer because each task has fewer available resources than when each task was performed separately (Wickens \& Hollands, 2000). However, Nigerian military domain has implemented a multi-sensory information presentation approach in order to counter soldiers stumble upon situations in which their visual and auditory channels are both heavily loaded at same time which positive affect have not been felt (Ujoatuonu, Kanu, Ugwuibe, \& Mbah, 2019).

Also according to the information processing theory, individuals have limited amount of resources available that influences their emotional, physical and mental wellbeing needed to complete a task (Pendergrass, Hamel, \& Salas, 1987). With this, the tendency that Nigerian military personnel fear of happiness will influence and increase their workload is very high. Although technological advancement should have helped modern combat, but it represents a highly complex task environment that poses many significant challenges (Sterling \& Perala, 2007) for soldiers in developing countries like Nigeria. For example, during a combat situation, there are varieties of information that a single soldier must attend to and comprehend, which becomes especially problematic when considering the high operational tempo, uncertainty, and stress of combat (Reid \& Nygren, 1988). This is enough to influence the experiences of happiness and workload of Nigerian soldiers. In summary, there are challenges involved in conveying battlefield information to the soldier in a manner that enhances their ability to manage the information and in turn, increases their situational awareness, thriving at work and 
proactivity in the face of perceived workload (Skinner \& Simpson, 2002). Researchers (Reid \& Nygren, 1988; Skinner \& Simpson, 2002) suggested that multisensory information display may be an effective technique for enhancing the information management and situational understanding of soldiers.

\section{Hypothesis}

H1. Fear of happiness will not significantly predict Nigerian military personnel work load.

H2. Fragility of happiness will significantly predict Nigerian military personnel work load.

\section{Method}

\subsection{Participants}

Our study participants comprised two hundred and twenty (220) serving military personnel's drawn from four (4) different Army Barracks and/or Divisions. The participants were drawn from several departments (e.g., Nigeria Army Amour Corps, Nigeria Army Corps of Artillery, Nigeria Army Engineers, Nigeria Army Medical Corps, Nigeria Army Signals, Nigeria Army Supply and Transport, Nigeria Army Electrical and Mechanical Engineers, Nigeria Army Storage and Armoury, Nigeria Army NIBATT Chaplain, Nigeria Army Control and Account, Nigeria Army Management Science and Technology, Nigeria Army Adjutant, Nigeria Army Command schools'. These participants were purposefully sampled and their age ranged from 19 to 58 years ( $M=39$ years). Also, participants age range was categorized as $97(41.1 \%)$ for personnel's below 30years of age, 91(41.1\%) for personnel's between 30-40years, 24(10.9\%) for personnel's between 41-50 years, 8(3.6\%) for personnel's above 50 years of age. As for their designation, 202(91.8\%) were for below officers rank and 18(8.2) were from officers rank and above. As for the years of service, 23(10-5\%) are personnel's within 1-10years, 103(46.8\%) for personnel's within 11-20years $94(42.7 \%)$ for those above 20years. As for monthly salary, 193(87.7\%) earn between $\$ 50,000-100,000,18(8.2 \%)$ earn between $\$ 100,000-200,000$ and $9(4.1 \%)$ earn between $\$ 200,000$ and above. With regards to marital status $67(30.5 \%)$ were single and $153(69.5 \%)$ are married. As for number of children, $73(33.2 \%)$ for $.00,71(32.3 \%)$ for 1.0 , and $76(34.5 \%)$ for 2.0 With regards to educational qualification, 66(30.0\%) had First School Leaving Certificate, 2(.9\%) had West African Senior School Certificate Examination, 15(6.8\%) had Ordinary National Diploma/National Certificate for Education, 43(19.5\%) had Higher National Diploma, 31(14.1\%) had Bachelor of Science, 47(21.4\%) had Master of Science, and 16(7.1\%) had Doctor of philosophy.

\section{Instruments}

Three instruments used in the present study for data collection, include: Workload Scale (WLS) (Swarnalatha, 2013), Fear of Happiness Scale (FOHS; Joshanloo, 2016a), Fragility of Happiness Scale (FHS; Joshanloo, 2016b).

\subsection{Work Load Scale (WLS)}

Work Load Scale was developed by Swarnalatha (2013) to measure work load of employees. The instrument is an 11 item questionnaire that is scored on a five-point likert rating format $(1=$ Strongly disagree to $5=$ Strongly agree $)$, so that low scores indicate low workload, while high scores indicated high levels of workload. Sample items include: "Coming up with new ideas to get appreciated in the organization creates work pressure"; "My responsibility at work increases my workload." The eleven items were combined to give a total score for the workload instrument. In order to validate the Workload Scale for the present study, a pilot study was conducted with sixty (60) army personnel drawn from $6^{\text {th }}$ Amphibious Division of the Nigerian Army in Portharcourt, Rivers State and yielded internal consistency reliability (Cronbach's alpha, $\alpha$ ) of the Workload Scale was .92. A factor analysis was run to test the factor structure of the Scale. The Kaizer-Meyer Olkin (KMO) value was .71 and the Bartlett's Test of Sphericity was $641.10(p<.001)$, indicating that the data can be tested for factorial validity. All the items loaded on a single factor with values of .59 to .78. The single dimension explained $53.13 \%$ of the variance in the Scale.

\subsection{Fear of Happiness Scale (FOHS)}

The fear of happiness scale was developed by Joshanloo (2016a) and was used to assess fear of happiness (e.g., "having lots of joy and fun causes bad things to happen"). The five items are rated on a 7-point scale ranging from Strongly disagree $=1$ to Strongly agree $=7$. The scale has shown acceptable statistical (1) properties across 14 nations, including Korea (Joshanloo, M., Lepshokova, Kh., Panyusheva, Natalia, Poon, Yeung, Sundaram, Achoui, Asano, Igarashi, Tsukamoto, Rizwan, Khilji, Ferreira, Pang, Ho, Han, Bae, \& Jiang, 2014). The scale was validated through a pilot study conducted by the researchers among a sample of sixty (60) army personnel drawn from $6^{\text {th }}$ Amphibious Division of the Nigerian Army in Port-Harcourt, Rivers state, to determine its reliability in the Nigerian sample. For the present study, the reliability of the fear of happiness was .89. A factor 
analysis showed that all the items of the scale loaded on one dimension with factor loadings of .30 and above, which explained $36.08 \%$ of the variance in the entire scale.

\subsection{Fragility of Happiness Scale (FHS)}

The 4-item fragility of happiness scale was developed by Joshanloo (2016b) was used to measure how easily broken happiness can be (e.g., "Happiness is fragile"). The items were rated on a 7-point scale ranging from strongly disagree (1) to strongly agree (7). The scale has shown acceptable statistical properties across 15 nations, including Korea (Joshanloo et al., 2015). The scale was validated through a pilot study conducted by the researcher among a sample of sixty (60) army personnel drawn from $6^{\text {th }}$ Amphibious Division of the Nigerian Army in Port harcourt, Rivers State to determine its reliability in Nigerian sample. Reliability analysis performed using the data collected from respondents yielded a Cronbach's alpha coefficient of .86 .

\section{Procedure}

The researchers first took permission from the General Officer in Command (GOCs) of the respective barracks and explained the nature and purpose of the study. A total of two hundred and fifty (250) questionnaires were distributed in which 227 were filled and returned, representing $91 \%$. The researchers discarded seven (7) copies of the questionnaires which were wrongly filled and (14) which were incompletely filled. Thus the researchers were left with two hundred (220) questionnaires for data analysis.

\section{Design/Statistics}

We conducted a survey research, and cross-sectional design was adopted in the study. Pearson's correlation (r) analysis was used to conduct the study's demographic variables, predictors plus dependent variables and was applied for testing the hypotheses.

\section{Results}

The results of the findings of this study are presented in this chapter. The correlations of the demographic variables and study variables are shown in Table 1.

Table 1. Correlations of demographic variables, fear of happiness, fragility of happiness and work load among Nigerian military personnel

\begin{tabular}{|c|c|c|c|c|c|c|c|c|c|}
\hline \multicolumn{2}{|c|}{ Variable } & 1 & 2 & 3 & 4 & 5 & 6 & 7 & 8 \\
\hline 1 & Age & - & & & & & & & \\
\hline 2 & Designation & .06 & - & & & & & & \\
\hline 3 & Years of service & -.01 & .06 & - & & & & & \\
\hline 4 & Income & .08 & $.64^{* * *}$ & .07 & - & & & & \\
\hline 5 & Number of children & $.34^{* * *}$ & $.16^{*}$ & .01 & .11 & - & & & \\
\hline 6 & Education & $.36^{* * *}$ & $.16^{*}$ & .07 & $.17^{* *}$ & $.83^{* * *}$ & - & & \\
\hline 7 & Fear of happiness & -.02 & -.04 & -.06 & -.13 & -.12 & $-.17^{*}$ & - & \\
\hline 8 & Fragility of happiness & .10 & .08 & -.04 & -.07 & -.04 & -.02 & $.34^{* * *}$ & - \\
\hline 9 & Work load & $.31^{* * *}$ & $.14^{*}$ & .05 & .02 & $.25^{* * *}$ & $.24^{* * *}$ & .02 & $.24^{* * *}$ \\
\hline
\end{tabular}

Designation $(0=$ Rank and file, $1=$ Officer $)$; Years of service $(0=$ Less than $1 ; 1=1-10$ years; $2=11-20$ years; Above 20 years); Income ( $0=$ Less than 20,$000 ; 1=20,000-50,000 ; 2=50,000-100,000 ; 3=100,000$ 200,000; Above 200, 000); Education ( $0=\mathrm{FSLC}, 1=\mathrm{WASSCE}, 2=\mathrm{OND} / \mathrm{NCE}, 3=4=\mathrm{HND}, 5=\mathrm{BSc}$; $6=$ $\mathrm{MSc}, 7=\mathrm{PhD})$.

Results of the Correlations in Table 1 showed that age was positively associated with number of children $(r=.34$, $p<.001)$, level of education $(r=.36, p<.001)$, and workload $(r=.31, p<.001)$. Being an officer was associated with higher income $(r=.64, p<.001)$, number of children $(r=.16, p<.05)$, higher education $(r=.16, p<.05)$, and more work load $(r=.14, p<.05)$. Higher year of service was not associated with any of the variables in the study. Higher income was related to higher educational qualification $(r=.17, p<.001)$. Number of children was positively associated with educational qualification $(r=.83, p<.001)$, and work load $(r=.25, \mathrm{~L} p<.001)$. Educational qualification was negatively associated with fear of happiness $(r=-.17, p<.05)$, and work load $(r$ $=.24, p<.001)$. Fear of happiness was positively correlated with fragility of happiness. Also, it was found that fear of happiness was not significantly associated with work load $(B=-.04)$. Fragility of happiness was positively and significantly associated with work load $(B=.19, \mathrm{p}=.001)$. For every one unit rise in fragility of 
happiness, work load increases by .19 units. In other words, higher reports of fragility of happiness were linked to greater workload among the military personnel in this study.

\section{Discussion}

The study investigated roles of fear of happiness and fragility of happiness on workload among Nigerian military personnel. The results indicated that fear of happiness was not significantly associated with workload. Thus, the first hypothesis which states that fear of happiness will not have a significant association with workload among Nigerian military personnel was confirmed and there are no related studies with military fear of happiness and workload. However, this result is consistent with studies on wellbeing (Diener, 1984; Diener, Suh, Lucas, \& Smith, 1999). This result seems to be consistent with the recent events in Nigeria which has made the job of Nigerian military personnel inherently demanding especially in answering distress calls. For example, been involved in challenges like insurrection, cross boarder crisis, peace keeping campaign in foreign countries, election violence, political uprising and agitations, Niger delta militancy, fight against Boko haram and Fulani herdsmen for months of years is enough to influence fear of happiness and workload. Being faced and identified with such demanding workload may require personnel to have different resilience, grit, commitment, hope and adaptation to workload management strategies which demands different personality fits and skills utilization techniques in combating these challenges, war fares and battles. Taken together, these may explain why fear of happiness was negatively associated with workload in the present study.

Lastly, the second hypothesis which stated that fragility of happiness will have a significant positive association with workload among Nigerian military personnel was accepted and findings agree with the results of Agbo, Nzeadibe and Ajaero (2012); DeBusk, Hill, Chander, Knight aand Babski-Reeves (2018); Joshanloo (2018) who observed the negative relationships between the predictors and subjective well-being were stronger for individuals who reported higher fragility of happiness. The less the capacity for action and motivation that enables personnel to do their work and attain desired goals, the less likely it is for them to be responsible in aiding workload. This finding suggests that the Nigerian military personnel who feel that they have physical strength, emotional energy, and cognitive liveliness may likely be unsuccessful in engaging the presenting workload because they will never actualize authentic happiness.

\section{Implications}

The study focused on roles of fear and fragility of happiness on workload among Nigerian military personnel. The results of the current study have important implications considering the fact that the military community is a closed-group system and Nigeria as a nation is in its worst state which needs restructuring. It is imperative to note that adequate enlightenment on fear, fragility and other experiences of happiness on workload with more industrial and social psychological variables need to be studied more as there are dearth of literatures in these areas. Therefore, owing to the importance of these challenging periods in Nigeria, scholars are advised to educate military communities, government and Nigerian citizens on how fear and fragility of happiness appear to decrease the likelihood that the Nigerian army personnel will engage military workload and enhance performance. In the current era, it may be unrealistic to minimize the fear and fragility of happiness of Nigerian military personnel. However, military personnel are known for the high fragility of happiness which serves as a suitable moderator to their workload. Nonetheless, we advise that during recruitment process, military management community can screen soldiers who have dynamic potentialities in adapting to different workload without any atoms of fear or fragility of happiness towards their workload.

\section{Limitations of the Study}

There were some limitations encountered during the research period. The nature of the research and the population sample posed a little problem. The participants were initially reluctant to respond, leading to the inhibition of some information. We had to assure them of confidentiality and that the information is purely for academic purpose before they could come out of their shells. Financial constraint was another great impediment. Thus, the sample size was too small for this kind of research. We recommend that future research should use larger number of participants by increasing sample size. This will enable the researchers make proper generalization of the research findings. Also, future researchers should be interested in other variables which may moderate workload. Such variables to be considered include: - Age, Designation, Type of employment, Years of service, Monthly salary, Marital status, Number of children, Age of children, Family size, Number of dependent Departments, State of origin, Educational qualification and personality profile. 


\section{References}

Agbo, A. A., Nzeadibe, C. T., \& Ajaero C. K. (2012). Happiness in Nigeria: A socio-cultural analysis. https://doi.org/10.1007/978-94-007-2700-7_20

Baba, K. A., Ujoatuonu, I. V. N., Ogba, K. T. U., \& Kanu, G. C., (2019). Political Influence on Military Wimpy in Organizational Commitment: Roles of Team Psychological Safety and Spirit at Work. Nigerian Journal of Social Psychology, 2(1), 166-184.

Billing, D. C., \& Drain, J. R. (2017). International congress on soldiers' physical performance 2017: Research priorities across the service members operational lifecycle. Journal Scientific Medical Sport, 20, S1-S3. https://doi.org/10.1016/j.jsams.2017.10.025

DeBusk, H., Hill, C. M., Chander, H., Knight, A. C., \& Babski-Reeves, K. (2018). Influence of military workload and footwear on static and dynamic balance performance. International Journal of Industrial Ergonomics, 64, 51-58. https://doi.org/10.1016/j.ergon.2017.11.003

Diaz-Piedra, D., Sebastián, M. V., \& Di Stasi, L. L. (2020). EEG theta power activity reflects workload among army combat drivers: An experimental study. Brain Studies, 10(199), 1-34. https://doi.org/10.3390/brainsci10040199

Diener, E. (1984). Subjective well-being. Psychological Bulletin, 95(3), 542-575. https://doi.org/10.1037/0033-2909.95.3.542

Diener, E., Suh, E. M., Lucas, R. E., \& Smith, H. L. (1999). Subjective well-being: Three decades of progress. Psychological Bulletin, 125(2), 276-302. https://doi.org/10.1037/0033-2909.125.2.276

Hart, S., \& Staveland, L. (1988). Development of a NASA-TLX: Results of empirical and theoretical research. In P. Hancock \& N. Meshkati (Eds.), Human mental workload. Amsterdam: Elsevier. https://doi.org/10.1016/S0166-4115(08)62386-9

Hart, S., \& Wickens, C. (1990). Workload prediction and assessment. In H. Booher (Eds.), Manprint: An approach to systems integration. New York: Van Nostrand Reinhold.

Hollands, J. G., Spivak, T., \& Kramkowski, E. W. (2019). Cognitive load and situation awareness for soldiers: Effects of message presentation rate and sensory modality. The Journal of the Human Factors and Ergonomics Society, XX(X), 1-11. https://doi.org/10.1177/0018720819825803

Joshanloo, M. (2019). Lay conceptions of happiness: Associations with reported well-Being, personality traits, and materialism. Frontiers in Psychology, 10(2377), 1-24. https://doi.org/10.3389/fpsyg.2019.02377

Joshanloo, M. (2013a). Conceptions of happiness across cultures. Doctoral dissertation, Victoria University of Wellington, New Zealand.

Joshanloo, M. (2013b). The influence of fear of happiness beliefs on responses to the satisfaction with life scale. Personality and Individual Differences, 54(5), 647-651. https://doi.org/10.1016/j.paid.2012.11.011

Joshanloo, M. (2014). Eastern conceptualizations of happiness: Fundamental differences with western views. Journal of Happiness Studies, 15(2), 475-493. https://doi.org/10.1007/s10902-013-9431-1

Joshanloo, M. (2018). Fragility of happiness moderates the influence of negative predictors of subjective well-Being. Anxiety, Stress, \& Coping, 31(2), 222-227. https://doi.org/10.1080/10615806.2017.1422094

Joshanloo, M., Park, Y. O., \& Park, S. H. (2017). Optimism as the moderator of the relationship between fragility of happiness beliefs and experienced happiness. Personality and Individual Differences, 106, 61-63. https://doi.org/10.1016/j.paid.2016.10.039

Joshanloo, M., Weijers, D., Jiang, D., Han, G., Bae, J., Pang, J., Ho, L., Ferreira, M. C., Demir, M., Rizwan, M., Khilji, I.A., Achoui, M., Asano, R., Igarashi, T., Tsukamoto, S., Lamers, S. M. A., Turan, Y., Sundaram, S., Yeung, V.W., Poon, W., Lepshokova, Z., Panyusheva, T., \& Natalia, A. (2015). Fragility of happiness beliefs across 15 national groups. Journal of Happiness Studies, 16, 1185-1210. https://doi.org/10.1007/s10902-014-9553-0

Joshanloo. M. (2016). Fear of Happiness Scale. Measurement Instrument Database for the Social Science. Retrieved from www.midss.ie

Mao, M., Xie, F., Hu, J., \& Su, B. (2014). Analysis of workload of tank crew under the conditions of informatization. Defence Technology, 10(1), 17-21. https://doi.org/10.1016/j.dt.2013.12.008 
Mitchell, D. K. (2000). Mental workload and ARL workload modeling tools; US Army Research Laboratory: Aberdeen, MD, USA Skinner, M. J., \& Simpson, P. A. (2002). Workload issues in military tactical airlift. The International Journal of Aviation Psychology, 12(1), 79-93. https://doi.org/10.21236/ADA377300

Pendergrass, V. E., Hamel, C. J., \& Salas, E. (1987). A Human Information Processing Theory of Skill Acquisition: A Training Systems View. Proceedings of the Human Factors Society Annual Meeting, 31(6), 643-647. https://doi.org/10.1177/154193128703100607

Reid, G. B., \& Nygren, T. E. (1988). The subjective workload assessment technique: A scaling procedure for measuring mental workload. In P. A. Hancock \& N. Meshkati (Eds.), Human mental workload. Amsterdam: Elsevier. https://doi.org/10.1016/S0166-4115(08)62387-0

Skinner, M. J., \& Simpson, P. A. (2002). Workload issues in military tactical airlift. The International Journal of Aviation Psychology, 12(1), 79-93. https://doi.org/10.1207/S15327108IJAP1201_7

Sterling, B. S., \& Perala. (2007). Workload, stress and situation awareness of soldiers who are controlling unmanned vehicles in future urban operations. ARL-TR-3628; U.S. Army Research Laboratory: Aberdeen Proving Ground, MD, 2005.

Swarnalatha, T. (2013). An empirical analysis of work life balance on women employees: a study with reference to banking sector at Chennai. $\mathrm{PhD}$ thesis. Retrieved from http://hdl.handle.net/10603/38349

Ujoatuonu, I. V. N., Kanu, G. C., \& Apex-Apeh, O. K. (2017). Vocational identity of Nigerian army personnel: Roles of spirit at work and energy at work. Nigerian Journal of Psychological Research, 13, 41-48.

Ujoatuonu, I. V. N., Kanu, G. C., Ugwuibe, O. C., \& Mbah, O. P. (2019). Role of Workplace support on the relationship between perceived work life balance policies and flourishing among Nigerian Military personnel's. Nigerian Journal of Psychological Research, 15, 39-45.

Ujoatuonu, I. V. N., Onyishi, A. B., Okafor, C. O., Amazue, L. O., \& Umeh, C. K. (2020). Organizational Identity and Career Transition as Predictors of Pre-retirement Anxiety among Nigerian Military Personnel. Enugu State University of Science and Technology Journal of Social Sciences, 5(1), 74-90.

Wickens, C. D. (2008). Multiple Resources and Mental Workload. Human Factors: The Journal of the Human Factors and Ergonomics Society, 50(3), 449-455. https://doi.org/10.1518/001872008X288394

Wickens, C. D., \& Hollands, J. G. (2000). Engineering psychology and human performance (3rd ed.). Upper Saddle River, NJ: Prentice Hall.

Wierwille, W., \& Casali, J. (1983). A validated rating scale for global mental workload measurement and application. Proceedings of the human factors society twenty-seventh annual meeting, 129-133. https://doi.org/10.1177/154193128302700203

\section{Copyrights}

Copyright for this article is retained by the author(s), with first publication rights granted to the journal.

This is an open-access article distributed under the terms and conditions of the Creative Commons Attribution license (http://creativecommons.org/licenses/by/4.0/). 